\title{
Identifying vocational education and training
}

\section{GAVIN MOODIE}

Victoria University of Technology, Australia

\begin{abstract}
This paper observes that vocational education and training's identity has been founded on four types of characteristics: epistemological, teleological, hierarchical and pragmatic. No single characteristic is found to be adequate to identify vocational education and training across jurisdictions and across historical periods. Both Rushbrook and Stevenson seek for vocational education and training what Rushbrook calls an 'abstracted institutional teleology'. Yet such a quest may degenerate into essentialism, and in any case is vulnerable to being made obsolete by the changes which vocational education and training is meant to be stimulating and equipping us for. The paper concludes by arguing for a definition of vocational education and training which is a compound of the four general characteristics considered.
\end{abstract}




\title{
Identifying vocational education and training
}

\author{
GAVIN MOODIE \\ Victoria University of Technology, Australia
}

\begin{abstract}
This paper observes that vocational education and training's identity has been founded on four types of characteristics: epistemological, teleological, hierarchical and pragmatic. No single characteristic is found to be adequate to identify vocational education and training across jurisdictions and across historical periods. Both Rushbrook and Stevenson seek for vocational education and training what Rushbrook calls an 'abstracted institutional teleology'. Yet such a quest may degenerate into essentialism, and in any case is vulnerable to being made obsolete by the changes which vocational education and training is meant to be stimulating and equipping us for. The paper concludes by arguing for a definition of vocational education and training which is a compound of the four general characteristics considered.
\end{abstract}

\section{Definitions of vocational education and training}

Over a century ago T H Huxley lamented that 'it passes the wit of man, so far as I know, to give a legal definition of technical education' (1877) and thirty years ago Clark warned of Canada that 'the non universities will fail us if they evolve only as carbon copies of the past or as institutions that zig and zag with the opportunism of the moment. A firm self concept is essential to their promising new role in society' (1971, quoted in Medsker, 1972). Arguably we are no further advanced in establishing a secure identity for vocational education and training.

I start by reviewing several definitions of vocational education and training, classifying them into four types: epistemological, teleological, hierarchical and pragmatic. I conclude by using those types to develop a compound definition of vocational education and training.

\section{Epistemological}

The most fundamental foundation of vocational education and training's identity is as the development of a distinctive way of knowing; some writers make associated claims for vocational education and training's distinctive way of learning, and some consider it a field of knowledge.

\section{Ways of knowing}

In Nichomachean Ethics Aristotle distinguished 'five ways in which the soul arrives at truth' pure science (episteme), art or applied science (techne), prudence or practical wisdom (phronesis), intelligence or intuition (nous) and wisdom (sophia). Wisdom or theoretical wisdom is knowledge of first principles and therefore is the most precise and perfect form of 
knowledge. Art or applied science is essentially a trained ability of rationally producing, or in other translations, producing under the guidance of true reason. Similarly in the Metaphysics Aristotle says that theoretical kinds of knowledge are more of the nature of wisdom than the productive or practical kinds of knowledge because they deal with the first causes and the principles of things.

James (1995) notes that different levels of reflection correspond to Habermas' different knowledge-constitutive interests: technical reflection (know how and know what), practical reflection ('what ought I do?') and critical reflection (development of relational autonomy).

There are various variants and partial applications of such epistemological distinctions. One of the earliest descriptions of 'technical instruction' is as the training of the hand, which is contrasted with the education of the mind (Magnus, 1881). While no one would propose such a crude Cartesian dualism now, many descriptions of vocational education tacitly propound other mind/body distinctions such as the distinction between knowing and doing and between theory and practice (Gonzci, 1997).

H S Williams argues that technical education is practical, in contrast to university education which is by implication (more) theoretical (1963) or academic. At other times Williams rests the distinctiveness of technical education on its applied nature in contrast to university education which is by implication more 'pure' (1965). At its most general this is a distinction between the abstract thought said to characterise general education and the concrete action thought to characterise vocational education (Gonczi, 1997). This is reflected in UNESCO's (1997) international standard classification of education which distinguishes between general education which is mainly designed to lead participants to a deeper understanding of a subject or group of subjects and 'vocational or technical education' which is mainly designed to lead participants to acquire the practical skills, know-how and understanding necessary for employment in a particular occupation or trade or class of occupations or trades. The international standard subdivides vocational programs into those that are primary theoretically oriented and those that are primarily practically oriented.

Associated with this dualism is the connotation if not definition of vocational education as being concerned with training to do repetitive tasks in contrast with higher level education which is considered adaptive, generative and innovative. This in turn can be reduced to a distinction between skill and knowledge (Stevenson, 1996, 1998).

Blunden (1995) and Stevenson (1995) note the modern association of general education with conceptual understanding or declarative knowledge and vocational education's association with demonstrated knowledge or procedural knowledge, which they trace to Ryle's (1951) distinction between knowing that and knowing how, between propositional knowledge and operational competence. Somewhat similar is Tight's (1996) distinction between understanding and practical experience.

Some contemporary vocational education reformers found its epistemological distinctiveness in being based on competence. One arm of the definition of vocational and technical education in the US federal education code is that it should 'include competency-based applied learning that contributes to the academic knowledge, higher-order reasoning and problemsolving skills, work attitudes, general employability skills, technical skills, and occupationspecific skills, of an individual' (legal information institute, 2002). Carnegie (2000) propounds a similar definition, at least for Australia - 
A distinguishing feature of VET is the specific learning/assessment focus, which is competency based. This approach is concerned with training and assessment to meet industry standards rather than with an individual's achievement relative to that of others in a group. It emphasises what a person can do, not just what they know.

\section{Ways of learning}

Note also that Carnegie's distinction is partly founded not on ways of knowing but on ways of learning. This resonates with vocational education's historical identification with apprenticeships, where the learning-teaching method is said to be by observation, imitation and personal correction, rather than by application of general propositions delivered in classrooms and text books. This in turn is related to a distinction between general education's verbal knowledge and vocational education's non verbal or tacit knowledge (Stevenson, 1998).

\section{As a field of knowledge}

Leonard Cantor (1989) distinguishes between 'general vocational education programmes, and occupational-specific programmes', the former including 'pre-vocational courses designed to introduce students to broad vocational areas, such as business and office education, home economics, and industrial arts', and general work and life skills. This describes vocational education not so much as a way of knowing as a broad field of knowledge comparable to social sciences, physical sciences and the humanities.

\section{Teleological}

Many thinkers found vocational education and training's identity on the purpose it serves; three types are identified here.

\section{Training for an extrinsic purpose compared with cultivation for intrinsic worth}

In the Metaphysics Aristotle distinguishes philosophy, the knowledge of first principles and causes, which 'alone of the sciences is free since it alone is pursued for its own sake' from other activities which are pursued for extrinsic reasons. In The Politics Aristotle contrasted the training for extrinsic purposes suitable for artisans, slaves and women with the cultivation of the arts for their intrinsic worth appropriate for leisured, free men. This informed the 'philosophy of civic humanism, espoused by those like the Earl of Shaftesbury, writing in the early 1700s, who revived a classical distinction between "liberal" arts (i.e. free, in the sense of civic freedom), and "mechanical”, "useful” or even "servile” artisanship. His aristocratic schema was firmly based on the idea that "trade" - commercial activity including creative work - was "servile” or even "slavish”, as in "slavish imitation”” (Cunningham \& Hartley, 2001).

It has also informed some modern conceptions of vocational education. Thus, B Williams (1970) argued that the 'inner logic' of university and advanced education provides a 'functional differentiation' between them, between university education's intrinsic value and vocational education's instrumental value (quoted in Hermann et al, 1976). Feinberg (1983) claims that the aim of vocational education is to transmit exploitable knowledge to participate in the market, whereas general education is to create a democratic society. Mitter (1988) recounts the establishment of secondary schools to draw a distinction between education as a preparation for work and education as a protection from work. 
As Dewey pointed out (1916), Aristotle's distinction between training for an extrinsic purpose and education for intrinsic worth is a special application of a more general distinction between means and ends. While this distinction between training and education has an attractive neatness, it is not an adequate characterisation of vocational education. For in vocational education as much as in higher education there is a continuum between studies taught and learned for instrumental purposes and those pursued for intrinsic interest. Furthermore, in both sectors a study that may be of mainly intrinsic interest to some scholars has more instrumental value to others: studies aren't one or the other for all scholars. Nonetheless, the distinction between means and ends has spawned cognate characterisations of vocational education.

Stevenson (1997) notes further differences in the valuing of knowledge, which interestingly he constructs more completely than the normal dualism: academic valuing of the production of new knowledge, general education's valuing of the development of the whole person for life, vocational education's valuing of competences for work, and some parts of adult education's valuing of critical thinking leading to empowerment.

\section{Training for work; education for life}

Newman's Idea of a university posited an ideal of humanist, liberal, holistic education which by implication was contrasted with instrumentalist, narrow education. He argued that one who has learned how 'to think and to reason and to compare and to discriminate and to analyse ... will not indeed at once be a lawyer, or a pleader, or an orator, or a statesman, or a physician . . . but he will be placed in that state of intellect in which he can take up any one of the sciences or callings ... . with an ease, a grace, a versatility, and a success'. Another early understanding of vocational education was that it was specialist, and in particular technical, in contrast to general education (Wilkinson, 1970, quoted in Hyland, 1999).

Ashby proposes a similar distinction between Bildung (education) and Ausbildung (training), or between Allgemeinbildung (general education) and berufliche Bildung (vocational education/training) as Jochimsen (1978) prefers. The editors of this journal, at least by implication, adopt a similar view that vocational education and training is education for work (Dhillon, 2002) -

Journal of Vocational Education and Training is a fully-refereed international journal that publishes scholarly articles addressing the development of practice and theory in work-related education, wherever that education occurs. In many industrial countries education for occupations is mainly a post-compulsory provision, though that is fast disappearing as those societies realise the fruitful potential for using work-oriented studies for general educational purposes in compulsory primary and secondary schooling.

But Ashby observes a major difficulty with such a distinction, at least put simply (Ashby, 1974) -

Notice that this distinction cuts across some familiar boundaries. It puts into the same category the education provided by the faculty of medicine at Cambridge and by the department of catering at Colchester Technical College; and it puts into the same category Oxford Greats and Workers' Education Association courses on archaeology. 
Notwithstanding the ahistorical claims that universities' modern vocationalism is a betrayal of their supposed essentially non-utilitarian virtues (Symes, 1999), from their foundation in the Middle Ages universities were largely vocational schools training for the church, medicine and the law (Cobban, 1975) and have expanded the vocations for which they train until the present time, as Dearing (1997) observed. Vocational orientation was assumed to be a pervasive feature of higher education by the editor and many of the contributors to a recent special issue of this journal on vocational qualifications in higher education (Roodhouse, 2000). So simple vocationalism is not sufficient to found technical education's distinctiveness (Kangan, 1974).

\section{Training for work directed by others, education for self-directed work}

Aristotle's distinction is also a distinction between training for slaves and artisans whose work is directed by others and education for free or self-directing men. This has been characterised as a distinction between training for paid employment and education for gentlemen of leisure (Wilkinson, 1970, quoted in Hyland, 1999) but such a distinction would not be seriously entertained in modern times.

More common has been a distinction between vocational education for paid employment and higher education for the professions. This might have had some value when there were fewer vocations claiming the status of profession and most professionals practised on their own account. But even then it had some uncomfortable anomalies. Insurance underwriting is a venerable, highly skilled vocation in which brokers have long practised on their own account we recall Shakespeare's Shylock and the 'names' of Lloyds of London - but insurance was very much 'trade' rather than a profession. And most of the practitioners of the profession whose training lead to the formation of many of our venerable universities - the clergy - were and remain employees of large bureaucracies, not independent practitioners.

These days most lawyers, engineers and many doctors are employees and so can't claim the autonomy of independent practice. Neither can they claim special status from their exercise of independent judgement - carpenters, personal care attendants and real estate agents, for example, all exercise considerable independent judgement in their work. But arguably the practitioners of the higher status vocations have more independence in the direction of their work than lower status workers. This distinction, then, collapses into a distinction of occupational level, which has informed many accounts of the distinctive character of vocational education.

\section{Hierarchical}

Three types of hierarchical classification are identified.

\section{By occupational level}

Plato expounds the view in The Republic that each person has different aptitudes which should be developed for the job to which they are best suited. Jobs in turn are commonly classified by level, and vocational education is also commonly defined by derivation from the occupational level of its graduates (Moorhouse 1960; Murray-Smith 1965; Hermann et al, 1976; Haslegrave, 1969). This has also been related to class (Hyde, 1983; Anderson, 1998; Young, 1993). H S Williams provided one of the most finely graded classifications (1961) - 
(i) trade

(ii) post trade

(iii) technician (production-maintenance)

(iv) technician (research design)

(v) professional

(vi) post professional.

The category of 'technician' was considered problematic, and Moorhouse (1960) and Williams $(1961,1963)$ clarify its categorisation carefully. While both authors believed that these occupational levels described the province of technical education, Moorhouse deprecated as 'a dangerous over-simplification' the ascription of institutional roles to occupational levels (1960).

But as Stevenson (1992) notes, just such an alignment of educational and occupational levels was institutionalised by the British national vocational qualifications. Australia sought to link rates of pay to composite educational-occupational levels in the restructuring of industrial awards from the late 1980s (Carmichael, 1992), leading to the reductive compartmentalisation of knowledge and hierarchies noted by Stevenson (1992). Stevenson posited six different skill levels, from the routine proceduralised tasks to management responsibility over others, and eight occupational levels, from operative to senior professional. This potentially generates 48 skill-occupational types and levels, although Stevenson observes that not all of the categories are used in practice.

\section{Educational level}

An obvious definition of vocational education is by educational level. Quebec neatly places its general and vocational colleges (collège d'enseignement général et professionnel) distinctively between secondary and higher education, since it is not possible to proceed from school to university without first completing the CEGEP's diploma of collegial studies (diplôme d'études collégiales) (Quebec, 2001). However, this neatness is unusual.

Commonly there is equivocation, first, on whether vocational education is truly tertiary education (Jakupec \& Roantree, 1993). Many vocational courses assume an educational level of 10 years of formal schooling, which suggests that at least many vocational courses are secondary in level (Murray-Smith, 1965). This leads some to argue that vocational education should be defined by students' achievement upon their exit rather on their entry to the sector (Williams, 1965) but this is hardly satisfactory.

Vocational education's reach has also been contested at the upper level. Following adoption of the Kangan report in Australia in the mid 1970s there was a contest between the technical and further education sector and the advanced education sector over associate diploma level qualifications (ACOTAFE, 1975) which advanced education won (TAFE Commission, 1976; Gooze, 1993). One history of vocational education is the development of upper levels of technical education which are progressively transferred to upwardly mobile institutions and sectors, a history which is shared at least by the UK (Hyland, 1999), Australia (Gooze, 1993) and Aotearoa-New Zealand.

Currently the Australian qualifications framework has an overlap between vocational education and training and higher education in responsibility for diplomas and for advanced diplomas (AQF, 2001) which at least some technical and further education commentators fear will result in higher education again taking over their more popular upper level courses. 
The traditional locus of vocational education in the US has been high schools, but secondary vocational enrolments declined substantially since the second half of the $20^{\text {th }}$ century (Hermann et al, 1976). The institutions that educate and train people for employment have grown in number and complexity over the past 30 years (Grubb, 1996). Increasingly vocational education takes place in post-secondary institutions including community colleges, technical institutes and area vocational schools (Grubb, 1996).

Medsker and Tillery noted attempts by leaders of US community colleges to establish a distinctive place between secondary and other post secondary schools (1971) but this has generally failed. In most US states community colleges have two roles: vocational education, which is shared with a plethora of other secondary and post-secondary institutions; and offering the first two years of baccalaureates, which is shared with four-year colleges and universities. This dual role places community colleges at an ambiguous level in US education.

Even community colleges' transfer role in providing the first two years of baccalaureates is problematic. It is clearly higher education in level. But direct admission to a four-year college or university is generally available only to students who complete their high school diploma with a grade point average in the top $30 \%$ or so (see, for example, CU-Boulder, 2001; Douglass, 2000), or for those who gain a comparable score in one of the national scholastic aptitude tests. Community colleges have open entry and thus admit students who do not meet the entry standards of selective colleges and universities, as well as students who meet these requirements but who prefer to take at least the first two years of their baccalaureate locally. So even this role is confounded for community colleges: they tend to be perceived to be of a lower level of higher education - that is, of a lower standard - because of their open entry.

So while vocational education may occupy a distinctive place amongst other educational sectors in some jurisdictions at some times, this is variable and contingent: it is different in different jurisdictions at any one time, and changes within many jurisdictions over time.

\section{Cognitive level}

Stevenson (1998) refers to Engestrom's (1994) hierarchy of learning: first order learning (conditioning, imitation and rote learning); second order learning (trial and error or learning by doing and problem solving or investigative learning); and third order learning (questioning and transforming the context or community of practice). This is sometimes mapped to educational levels, with vocational education said to involve first and second order learning and higher education involving second and third order learning and the development of Schon's critically reflective practitioner.

UNESCO’s (1997) international standard classification of education makes a related distinction between the programs that that give 'access to professions with high skills requirements (e.g. medicine, dentistry, architecture, etc.), and those programs which are practical/ technical/ occupationally specific' and which by implication have low skill requirements.

\section{Pragmatic - not elsewhere included}

A common definition of vocational education is the education which is not secondary or higher education (Stevenson, 1998). In the United Kingdom 'the further education sector may be described as the "ragbag” into which are deposited courses not provided elsewhere' (THES, 
1973) and Parkes describes Britain's further education sector as filling the gaps not filled by alternative sectors (1991).

Such is the diversity of arrangements in Canada that Dennison and Gallagher suggest that it may have been a strategic error to call the new post-secondary institutions 'colleges' because that term had been used to identify so many different kinds of institutions; indeed, the term had become so imprecise as to be almost meaningless (1986).

The Kangan committee established a mission for technical and further education in Australia from the mid 1970 to the mid 1990s, which is still influential in shaping the scope and values of the sector. But Kangan did not define an identity for the sector, as it itself acknowledged. The opening sentence of the committee's report describes its role and that of technical and further education residually - that left over from the other sectors (Kangan, 1974) -

The concept central to this report is the provision of unrestricted access to post school education through government maintained or administered institutions not already assisted through the Australian Universities Commission or the Australian Commission on Advanced Education.

The committee acknowledged interest in a precise definition of technical and further education but 'it believes that it is beyond human capacity to devise a precise definition of technical or further education that would stand the test of time' (Kangan, 1974). So technical and further education was the 'leftover' parts of education after the other sectors were created. Similarly, part of the definition of vocational and technical education in the US federal education code is that it prepares individual 'for careers (other than careers requiring a baccalaureate, master's, or doctoral degree)’ (legal information institute, 2002).

Rushbrook observes that Australian vocational education is 'the product of agency and organisational culture rather than an abstracted institutional teleology' (1997). This followed Murray-Smith's authoritative observation that 'the "received" definitions of technical education change radically from one era to another' (1965) and that the sector has a 'mutation gene' to adapt to new circumstances (1966, quoted in Rushbrook, 1997).

\section{Discussion}

Such pragmatism is considered a strength by some writers. In a paper descriptively titled 'Chameleon or phoenix: the metamorphosis of TAFE' Anderson charted the changes in the identity of Australian technical and further education 'which to date have threatened TAFE's survival as a distinct sector of education and training' (1998). Nonetheless, Anderson considers vocational education and training's adaptation to contemporary needs and circumstances to be a strength.

On the other hand, Stevenson (1998) argued that 'one of the most problematic issues for vocational education and training is the achievement of a positive purpose (subject to constructive criticism), characterised by clarity, coherence and continuity'. Vocational education's lack of a secure identity (Gooze, 1993) is one possible explanation for its defensiveness in its relations with higher education (Rushbrook, 1997; for a prominent Australian example see Schofield, 1998, 2000). It is also arguably an obstacle to building the seamless web of post compulsory education that is considered necessary to support lifelong learning (Wheelahan, 2000; Temple, 2001). 
There are a number of difficulties with founding vocational education and training's identity on a single characteristic. We have seen that no single characteristic consistently identifies vocational education and training in different jurisdictions or even in the same jurisdiction over different historical periods. Since a characteristic used to identify vocational education and training at one time has had to been changed as vocational education and training itself adapted and changed, it is unlikely that any single characteristic we identify now will be adequate to encompass the next historical shift. It may not even be desirable to fix vocational education and training on a single characteristic since this may introduce a rigidity which thwarts the very changes in society and the nature of work that vocational education and training is meant to be stimulating and equipping us for.

A characteristic such as Rushbrook’s ‘abstracted institutional teleology’ or Stevenson’s 'positive purpose ... characterised by clarity, coherence and continuity' would overcome many of these difficulties. But we have been unable to identify such a purpose of sufficient generality to encompass vocational education and training even in the jurisdictions we have considered while at the same time being sufficiently precise to delineate it from other forms of education. Neither have we found a purpose that encompasses vocational education and training's past, let alone being a guide for the future.

Yet we clearly identify vocational education and training when we see it, presumably using Wittgenstein's family resemblance (1968). An alternative approach is therefore to establish vocational education and training's identity not on a unique characteristic, but on a unique combination of characteristics. In its 1996/7 annual report the Australian federal government's vocational education body described vocational education and training as 'postcompulsory education and training that provides people with the skills and learning required by enterprises and industries' (ANTA 1997), thus combining characteristics of educational level, content and purpose. US federal legislation defines vocational and technical education as a combination of several characteristics (legal information institute, 2002).

Wellington (1993) argues that vocational education is technocratic, specific, practical and managerial; while general education is democratic, egalitarian, critical and collaborative, and Stevenson (2000) assembled a dozen pairs of general and vocational education dualisms. White (2001) observes of Ireland that 'the characteristics of those [technical] colleges have been identified as a) the provision of course programs of shorter duration than universities, b) the practical orientation of curricula, c) responsiveness to industry and business, d) limited ranges of subjects mostly in engineering and business studies, e) little, or only applied research and f) heavy teaching loads for faculty.'

These compound definitions are rather too specific, and it is unclear whether an activity needs to have all the characteristics precisely to be considered vocational education and training. The better approach is to define vocational education and training by the four general characteristics we have considered - epistemological, teleological, hierarchical and pragmatic. Thus, one may consider vocational education and training to be the development and application of knowledge and skills for middle level occupations needed by society from time to time.

This definition relies on the concept of applied knowledge as if Aristotle's notion of art or applied science (techne) is adequate, which it clearly isn't without elaboration. It also locates vocational education and training by occupational level thus making it subject to shifts in occupational hierarchy and economic structure. While it would be more satisfying to locate 
vocational education and training by educational level, this is probably the preference of an educationalist not shared by employers, workers and government.

Note

An earlier version of this paper was presented at the fourth Australian VET Research Association Conference, Adelaide, Australia, 2000. I thank one of this journal's anonymous reviewers for their generous suggestions to improve the paper.

\section{Correspondence}

Gavin.Moodie@bigpond.com; fax +61 +3 9284 8778, tel +61 +3 9284 8947; 245 Geelong Road, WEST FOOTSCRAY, 3012, Australia.

\section{References}

Anderson, Damon (1998) Chameleon or phoenix: the metamorphosis of TAFE, Australia and New Zealand Journal of Vocational Education Research, 6 (2), pp 1-43 at pp. 1, 6-7.

Aristotle, Nichomachean Ethics, book VI, 3. the qualities by which truth is obtained, 1139b1141a, Ostwald, Martin (trns) Indianapolis: the Bobbs-Merrill Company, p 150.

Aristotle, Metaphysics, Ross, W D (trns), book A, ch 1, 981b, book a, ch 1, 993b, $2^{\text {nd }}$ edition 1928. Oxford: Clarendon Press.

Aristotle, The Politics, Sinclair, T A (trns), Saunders, Trevor J (revised) (1992), book VIII, London: Penguin Books.

Ashby, Eric (1974) Adapting universities to a technological society, p. 135. : San Francisco: Jossey-Bass Publishers.

Australian committee on technical and further education (ACOTAFE) (1975) TAFE in Australia. Second report on needs in technical and further education, p. 109. Canberra: Australian Government Publishing Service.

Australian National Training Authority (1997) 1996/7 Annual performance report, p 8, Brisbane: ANTA, http://www.anta.gov.au.

Australian Qualifications Framework (AQF) (2001) Twelve AQF qualifications http://www.aqf.edu.au/twelve.htm

Blunden, Ralph (1995) 'Practical intelligence and the metaphysics of competence', Australian and New Zealand Journal of Vocational Education Research, 3(2), p 5.

Cantor, Leonard (1989) 'The "re-visioning” of vocational education in the American high school', Comparative Education, volume 25 no 2, pp 125-132. 
Carmichael, Laurie (1992) The Australian vocational certificate training system (the Carmichael report), Canberra: Employment and Skills Formation Council, National Board of Employment, Education and Training.

Carnegie, Jane (2000) Pathways to partnerships, p 18, Canberra: AVCC, http://www.avcc.edu.au/students/credit\%5Ftransfer/final\%5Freport.htm

Cobban, Alan B (1975) The medieval universities: their development and organisation, London, Methuen \& Co, p 165.

CU-Boulder (2001) Academic profile - new freshmen by college http://www.colorado.edu/admissions/profile.html

Cunningham, Stuart \& Hartley, John (2001) 'Creative industries-from Blue Poles to fat pipes', p 2, paper presented to the National Humanities and Social Sciences Summit-2001: Canberra, http://www.detya.gov.au/highered/respubs/humanities/summit701.pdf

Dearing, John (1997) (chair) Report of the national committee of inquiry into higher education, paragraph 10.20, http://www.leeds.ac.uk/educol/ncihe/

Dennison, John D \& Gallagher, Paul (1986) Canada's community college. A critical analysis, p. 142. Vancouver: University of British Columbia Press.

Dewey, John (1916) Democracy and education: an introduction to the philosophy of education, p 346, New York: The Free Press.

Dhillon, Jaswinder (2002) 'About the journal', Journal of Vocational Education and Training, http://www.triangle.co.uk/vae/index.htm

Douglass, John Aubrey (2000) Institutional differentiation and coordination: a case study of California, p. 4, mimeo, Berkeley: Centre for Studies in Higher Education, University of California.

Engestrom, Y (1994) Training for change, Geneva: Labour office.

Feinberg, W (1983) Understanding education: towards a reconstruction of educational inquiry, Cambridge: Cambridge University Press.

Gonczi, Andrew (1997) 'Future directions for vocational education in Australian secondary schools', Australian and New Zealand Journal of Vocational Education Research, 5(1), p 84, 87.

Gooze, G (1993) The development of TAFE in Australia. An historical perspective, pp. 6, 7. Adelaide: NCVER.

Grubb, Norton W (1996) Learning to earn all over again: current issues in vocational education and training in the United States in Selby Smith, C \& Ferrier, Fran (eds) The economic impact of vocational education and training, , pp 30-85, at pp. 30, 57. Canberra: Australian Government Publishing Service.

Haslegrave, H L (chair) (1969) Report of the committee on technical courses and examinations, p. 3, London: HMSO. 
Hermann, G D, Richardson, E \& Woodburne, G J (1976) Trade and technical education. Principles and issues, pp. 6, 16, 33, 187. Stanmore, NSW: Cassell Australia.

Huxley, Thomas Henry (1877) Technical education in Collected essays III. London.

Hyde, Jim (1983) The development of Australian tertiary education to 1939 in Murray-Smith, Stephen (ed) Melbourne studies in education 1982, pp 105-140, at p. 121. Parkville: Melbourne University Press.

Hyland, Terry (1999) Vocational studies, lifelong learning and social values. Investigating education, training and NVQs under the new deal, p. 27. Aldershot: Ashgate.

Jakupec, V \& Roantree, B (1993) Impact of the Martin report on technical and further education, in Meek, L V \& Harman, G (eds) The binary experiment for higher education: an Australian perspective, pp 151 - 165 at p. 151. Armidale: Department of Administrative, Higher and Adult Education Studies, University of New England.

James, Pauline (1995) 'Models of vocational development revisited: reflecting on concerns' The Vocational Aspects of Education, vol 47, no 3, p 298.

Jochimsen, Reimut (1978) 'Aims and objectives of German vocational and professional education in the present European context', Comparative Education, volume 14 no 3 (October), pp 199-209.

Kangan, Myer (chair) Australian Committee on Technical and Further Education (1974) TAFE in Australia. Report on needs in technical and further education, pp. xxvi, 2, 5-6. Canberra: Australian Government Publishing Service.

Legal information institute (2002) US code collection, title 20, chapter 44, section 2302, subsection 29, http://www4.law.cornell.edu/uscode/20/2302.html

Magnus, Philip (1881) Industrial education, p. 26. London: Kegan, Paul, Trench \& Co.

Medsker, Leland L (1972) The global quest for educational opportunity, p. 79. Berkeley: Center for research and development in higher education, University of California.

Medsker, Leland L \& Tillery, Dale (1971) Breaking the access barriers: a profile of two-year colleges, p. 60. New York: McGraw Hill.

Mitter, Wolfgang (1988) 'problems of the interrelationship between general and vocational education in Europe: a historical and conceptual approach’ in Rohrs, Herman (ed) Vocational and general education in western industrial societies, London: Symposium Books.

Moorhouse, C E (1960) Technical and technological education in Australia, The Australian Journal of Education, 4, 3, pp 175-90, at pp. 176, 178, 183.

Murray-Smith, S (1965) Technical education in Australia: a historical sketch, in Wheelwright, E L (ed) Higher education in Australia, pp 170-91 at pp. 170, 186, 189. Melbourne: F W Cheshire. 
Murray-Smith, S (1966) A history of technical education in Australia: with special reference to the period before 1914, p. 217. PhD thesis, Parkville: University of Melbourne.

Newman, John Henry (1959, first published 1853) The idea of a university, (1 ${ }^{\text {st }}$ ed) Image Books: New York.

Parkes, David (1991) Home thoughts from abroad: diagnosis, prescription and prognosis for British vocational education and training European Journal of Education, vol 26, no 1, pp 4153, at p. 42.

Plato The Republic, Lee, Desmond (trns) (1974) part two, 370, b - c, pp 118-9; and part four, 415, b - c, p 182, $2^{\text {nd }}$ ed, London: Penguin Books.

Quebec Ministere de l'education (2001) Education in Quebec

http://www.meq.gouv.qc.ca/rens/brochu/anglais/m_educaqc.htm

Roodhouse, Simon (2000) Editorial. Vocational Qualifications in Higher Education, Journal of Vocational Education and Training, volume 52, number 4.

Rushbrook, Peter (1997) Tradition, pathways and the renegotiation of tafe identity in Victoria, Discourse: studies in the cultural politics of education, vol 18, no 1, pp 103-112, at p. 104.

Ryle, Gilbert (1951) The concept of mind, London: Hutchinson’s University Library.

Schofield, Kaye (1998) University-tafe collaboration: the kiss of death? Paper to the $22^{\text {nd }}$ ATEM conference: Darwin http://www.ntu.edu.au/local/atem/conference/plenary/p2.pdf

Schofield, Kaye (2000) 'Traineeships: lessons from three reviews', answer to question from the audience 15 August (author's notes), presentation to Victoria University of Technology, Melbourne.

Stevenson, John (1992) 'Australian vocational education: learning from past mistakes?, The Vocational Aspects of Education, volume 44, number 2, pp 236-7.

Stevenson, John (1995) 'The political colonisation of the cognitive construction of competence’ The Vocational Aspect of Education, volume 47, no 4, pp 353-364.

Stevenson, John (1996) 'The metamorphosis of the construction of competence' Studies in Continuing Education, vol 18, no 1, pp 24-42.

Stevenson, John (1997) 'Legitimate learning', Australia and New Zealand Journal of Vocational Education Research, 5 (2), pp 1-43 at pp. 1, 6-7.

Stevenson, John (1998) 'Finding a basis for reconciling perspectives on vocational education and training', Australia and New Zealand Journal of Vocational Education Research, 6 (2), pp 134-165 at pp. 134, 135, 155.

Symes, Colin (1999) "Working for your future": the rise of the vocationalised university, Australian Journal of Education, 43, 3, pp 241-56.

Stevenson, John (2000) 'Working knowledge', Journal of Vocational Education and Training, volume 52, number 3, pp 503-519 at p 512. 
Technical and further education (TAFE) commission (1976) Report for the triennium 19771979, p. 100. Canberra: Australian Government Publishing Service.

Temple, Paul (2001) 'The HE/FE divide: is the end in sight?', Perspectives, vol 5, no 3, pp 7882.

Tight, Malcolm (1996) ‘Changing concepts in adult education’ Studies in Continuing Education, vol 18, no 1, pp 59-72.

Times Higher Education Supplement (1973) Wearing of the green, 2 February, p.1, quoted in Hermann et al (1976).

United Nations Educational, Scientific and Cultural Organisation (1997) International Standard Classification of Education http://www.unesco.org/education/docs/isced_1997.htm

Wellington, J J (1993) The work related curriculum, London: Kogan Page.

Wheelahan, Leesa (2000) Bridging the divide: developing the institutional structures that most effectively deliver cross-sectoral education and training. Adelaide: National Centre for Vocational Education Research.

White, Tony (2001) Investing in people: higher education in Ireland from 1960 to 2000, Institute of Public Administration: Dublin.

Wilkinson, R H (1970) The gentleman ideal and the maintenance of a political elite in Musgrave, P W (ed) Sociology, history and education, p. 133. London: Methuen.

Williams, B (1970) A functional differentiation? Vestes pp 121-125.

Williams, H S (1961) Technical education - State or national?, The Australian Journal of Higher Education (formerly The Educand) 1, 1, 98-103 at pp. 101, 103.

Williams, H S (1963) Tertiary technical in Australia, The Australian University, 1, 1, 89-119 at pp. 92, 112.

Williams, H S (1965) The technical colleges, in John Wilkes (ed) Tertiary education in Australia, pp 66-85, at pp. 71, 75. Sydney: Angus and Robertson.

Wittgenstein, Ludwig (1968) Anscombe, G E M (trns) Philosophical investigations, Oxford: Basil Blackwell.

Young, Michael (1993) 'A curriculum for the $21^{\text {st }}$ century? Towards a new basis for overcoming academic/vocational divisions', British Journal of Educational Studies, vol XXXXI no 3 (September), pp 203-222.

identifying1.doc 